Key Concepts and Terms // Journal of Industrial Ecology, Special Issue: Exploring the Circular Economy, Vol. 21, No.3, 2017, pp. 517525.

15. Ellen-MacArthur-Foundation and Granta Circularity indicators. An approarch to measuring circularity. Methodology, 2017, $98 p$

16. Ellen-MacArthur-Foundation., 2013a. Towards the circular economy. Economic and business rationale for an accelerated transition, Vol. 1.

17. Ellen-MacArthur-Foundation., 2013b. Towards the circular economy. Opportunities for the consumers goods sector. Ellen MacArthur Foundation, Vol. 2.

18. European Commission. Closing the loop - An EU action plan for the Circular Economy. Communication from the Commission to the European Parliament, the Council, the European Economic and Social Committee and the Committee of the Regions. Brussels, 2.12.2015, COM (2015) 614 final.

19. European Academies' Science Advisory Council policy report 30, Indicators for a circular economy, 2016, 35 p.

20. Elia, V., Gnoni, M.G., Tornese, F. Measuring circular economy strategies through index methods: A critical analysis // Journal of Cleaner Production, Vol. 142, No. 4, 2016, pp. 2741-2751.

21. Federal Law Gazette I, page 2705 'Closed Substance Cycle and Waste Management Act', 27 September 1994.

22. Franklin-Johnson, E., Figge, F., Canning, L. Resource duration as a managerial indicator for Circular Economy performance // Journal of Cleaner Production, Vol. 133, 2016, pp. 589-598.

23. Figge, F., Thorpe, A.S., Givry, P., Canning, L., Franklin-Johnson, E. Longevity and Circularity as Indicators of EcoEfficient Resource Use in the Circular Economy // Ecological Economics, Vol. 150, 2018, pp. 297-306.

24. Geissdoerfer, M., Savaget, P., Bocken, N.M.P., Hultink, E.J. The Circular Economy - A new sustainability paradigm? // Journal of Cleaner Production, Vol. 143, 2017, pp. 757-768.

25. Gladyshev N.G. Scientific basics of recycling in techno-natural waste management clusters, Dissertation for obtaining the scientific degree of the doctor of technical sciences. Specialty: 03.02.08 Ecology (by branches), Samara, 2013, $301 \mathrm{p}$.

26. Ghisellini, P., Cialani, C., Ulgiati S. A review on circular economy: the expected transition to a balanced interplay of environmental and economic systems // Journal of Cleaner Production, Vol. 114, 2016, pp. 11-32.

27. Greyson, J. An economic instrument for zero waste, economic growth and sustainability // Journal of Cleaner Production, Vol. 15, No. 13-14, 2007, pp. 1382-1390.

28. Guidelines for National Waste Management Strategies Moving from Challenges to Opportunities. United Nations Environmental Programme, 2013, 112 p.

29. Haas, W., Krausmann, F., Wiedenhofer, D., Heinz, M. How circular is the global economy?: an assessment of material flows, waste production, and recycling in the European union and the world in 2005 // Journal of Industrial Ecology, Vol. 19, No. 5, 2015, pp. 765-777.

30. lacovidou, E., Velis, C.A., Purnell, P., Zwirner, O., Brown, A., Hahladakis, J., Millward-Hopkins, J., Williams, P.T. Metrics for optimising the multi-dimensional value of resources recovered from waste in a circular economy: A critical review // Journal of Cleaner Production, Vol. 166, 2017, pp. 910-938.

31. Kirchherr, J., Reike, D., Hekkert, M. Conceptualizing the circular economy: An analysis of 114 definitions // Resources, Conservation and Recycling, Vol. 127, 2017, pp. 221-232.

32. Law of Environment Agency Japan 'The Basic Act for Establishing a Sound Material-Cycle Society', No.110, 2.06.2000.

33. Le bre E., Corder G., Golev A. The Role of the Mining Industry in a Circular Economy. A Framework for Resource Management at the Mine Site Level // Journal of Industrial Ecology, Special Issue: Exploring the Circular Economy, Vol. 21, No. 3, 2017, pp. 662-672.

34. Linder, M., Sarasini, S., van Loon, P. A Metric for Quantifying Product-Level Circularity // Journal of Industrial Ecology, Special Issue: Exploring the Circular Economy, Vol. 21, No. 3, 2017, pp. 545-558.

35. Moula, M.E., Sorvari J., Oinas P. Constructing a green circular society, Helsinki: University of Helsinki, 2018, 164 p.

36. Moreno, M., Rios, C., Rowe, Z., Fiona, C. A Conceptual Framework for Circular Design Sustainability // Sustainability, Vol. 8, No. 9, 2016, p. 937.

37. Moriguchi, Y. Material flow indicators to measure progress toward a sound material-cycle society // Journal of Material Cycles and Waste Management, Vol. 9, No. 2, 2007, pp. 112-120.

38. Murray, A., Skene, K., Haynes, K. The Circular Economy: An Interdisciplinary Exploration of the Concept and Application in a Global Context // Journal of Business Ethics, Vol. 140, No. 3, 2015, pp. 369-380.

39. Order of the President of the People's Republic of China 'Circular Economy Promotion Law of the People's Republic of China' No. 4, 29.08.2008.

40. Pauliuk, S. Critical appraisal of the circular economy standard BS 8001:2017 and a dashboard of quantitative system indicators for its implementation in organizations // Resources, Conservation \& Recycling, Vol. 129, 2018, pp. 81-92.

41. Park, J.Y., Chertow, M.R. Establishing and testing the 'reuse potential' indicator for managing wastes as resources // Journal of Environmental Management, Vol. 137, 2014, pp. 45-53.

42. Pomponi, F., Moncaster A. Circular economy for the built environment: A research framework // Journal of Cleaner Production, Vol. 143, 2017, pp. 710-718.

43. Shevchenko, T., Laitala, K., Danko, Yu. Understanding Consumer E-Waste Recycling Behavior: Introducing a New Economic Incentive to Increase the Collection Rates // Sustainability, Vol. 11, No. 9, 2019, pp. 2656. 
44. Shevchenko, T., Kronenberg, J. Management of material and product circularity potential as an approach to operationalise circular economy // Progress in Industrial Ecology, An International Journal, Vol. 14, No.1, 2020, pp. 30-57.

45. Shevchenko, T., Danko, Yu., Krasnorutskyy, O. Management of waste electrical and electronic products in compliance with the circular economy: What are the future Challenges for EU Member States? // International Journal of Ecology and Development, Vol. 3, No. 33, 2018, pp. 47-55.

46. Saidani, M., Yannou, B., Leroy, Y., Cluzel, F., Kendall, A. A taxonomy of circular economy indicators // Journal of Cleaner Production, Vol. 207, 2019, pp. 542-559.

47. Saidani, M., Yannou, B., Leroy, Y., Cluzel, F. How to Assess Product Performance in the Circular Economy? Proposed Requirements for the Design of a Circularity Measurement Framework // Recycling, Vol. 2, No. 1, 2017, p. 6.

48. Skene, K.R. Circles, spirals, pyramids and cubes: why the circular economy cannot work // Sustainability Science, published online: 5.05.2017.

49. Stahel, W., Reday-Mulvey, G. Jobs for tomorrow: The potential of substituting energy for manpower. Brussels; New York: Vantage, 1981.

50. Stahel, W. The Performance Economy, Second Edition, Palgrave-MacMillan, London, 2010, 350 p.

51. Telizhenko, O., Shevchenko, T., Mishenina, G. Sustainable Management of the Municipal Solid Waste Resource Potential in the Context of Product Lifecycle Continuity // Journal of Environmental Management and Tourism, Vol. 16, No. 4, 2016, pp. 664-671.

52. Velis, C.A, Brunner, P.H. Recycling and resource efficiency: it is time for a change from quantity to quality // Waste Management \& Research, Vol. 31, No. 6, 2013, pp. 539-540.

53. Wastling, T., Charnley, F., Moreno, M. Design for Circular Behaviour: Considering Users in a Circular Economy // Sustainability, Vol. 10, No. 6, 2018, p. 1743.

54. Weelden E., Mugge, R., Bakker, C. Paving the way towards circular consumption: exploring consumer acceptance of refurbished mobile phones in the Dutch market // Journal of Cleaner Production, Vol. 113, 2016, pp. 743-754.

55. Zaman, A.U. Review: A comprehensive review of the development of zero waste management: lessons learned and guidelines // Journal of Cleaner Production, Vol. 91, 2014, pp. 1-14.

Shevchenko T., PhD, Associate Professor, Sumy National Agrarian University (Sumy, Ukraine)

Methodological approach to measuring progress towards a closed-loop economy model

The novelty of this study is to refine a methodological approach towards measuring the circular economy progress based on the evaluation of indicators by individual segments of the resource cycle. In our view, the segmentation of the resource cycle could be an effective tool for measuring the progress towards a circular economy by investigating structural changes in the resource cycles of the territory caused by closing and slowing the material loop. Existing practices of measuring the progress, based mainly on reuse and recycling indicators, does not fully reflect such concepts as the lifecycles of a material and product, measured by the number of turns and duration. Besides, metrics need to be developed to answer the question of how fully the available circularity potential is used to provide the implementation of 6 Rs strategies for a particular territory. The findings are the basis for developing a circular data framework for enterprises in all economic sectors from mining of raw materials to manufacturing of finished products, from collection of endof-life products via restoration to manufacturing of recycled products.

Key words: circular economy, closed-loop economy, circular metrics, progress measuring, recycling, resource cycle, reuse, waste management.

Дата надходження до редакції: 17.11.2019 р. 


\title{
УДОСКОНАЛЕННЯ АКЦИЗНОГО ОПОДАТКУВАННЯ В УКРАЇНІ В УМОВАХ ІНТЕГРАЦІЇ ДО ЄС
}

\author{
Ярош Марта Володимирівна \\ кандидат економічних наук \\ Апарат Верховної ради України \\ ORSID 0000-0002-6299-4755 \\ yarosh0812@gmail.com \\ Прокіпчук Левко Ігорович \\ аспірант \\ Львівський національний університет імені Івана Франка \\ ORSID 0000-0003-3979-3100 \\ prokipchuk0017@gmail.com \\ Галамай Роман Ярославович \\ аспірант \\ Львівський національний університет імені Івана Франка \\ ORSID 0000-0003-0120-696X \\ galamaj0017@gmail.com
}

У статті досліджено питання удосконалення акцизного оподаткування в Україні в умовах інтеграції національного законодавства до вимог Європейського Союзу. Зазначені Директиви ЄС у відповідності до яких необхідно привести до відповідно вітчизняне законодавство. Визначені основні проблеми, які слід подолати в напрямку гармонізації національних нормативно-правових актів до вимог ЄС. Запропоновано схему оподаткування акцизним податком маркетингових послуг, наданих підприємствам-виробникам алкогольної продукції/тютюнових виробів. Вказано на наслідки, які виникнуть від запровадження акцизного податку на маркетингові послуги, що надаються підприємствам-виробникам алкогольної продукції/тютюнових виробів. Рекомендовано переглянути систему надання пільг зі сплати акцизного податку в напрямку наближення до норм ЄС та їх формування відповідно до таких векторів: підтримка виробництва національного продукту, який характеризується історією свого виготовлення та відповідною рецептурою; підтримка малих виробників в сфері виготовлення алкогольних напоїв, зокрема, виноробів. Визначено основні напрями удосконалення оподаткування акцизним податком. Як висновок можна зазначити, що перш за все необхідно вжити наступних заходів для ефективної гармонізації податкового та митного законодавства до норм ЄС: автоматизація процесів адміністрування справляння податків та митних платежів; гармонізація законодавчої системи в сфері акцизного та митного оподаткування; формування акцизної та митної політики з пріоритетністю підтримки національного виробника та малого бізнесу.

Ключові слова: акцизний податок, Європейський Союз, асоціація, митні платежі, оподаткування маркетингових послуг.

DOI: https://doi.org/10.32845/bsnau.2019.4.7

Постановка проблеми. В рамках підписання угоди «Про асоціацію між Україною та ЄС», вітчизняну податкову систему слід гармонізувати відповідно до норм та правил Європейського Союзу для посилення співпраці та подолання шахрайства, контрабанди та корупційних схем в економічному просторі і країн-членів ЄС, і України. Передовсім це питання стосується непрямого оподаткування, оскільки саме система непрямого оподаткування найбільше страждає від контрабандних поставок товарів на територію обох утворень.

Аналіз останніх досліджень та публікацій. Теоретичні та практичні аспекти розвитку непрямого оподаткування досліджували такі вітчизняні вчені, як В.Л. Андрущенко, В.А. Валігура, О.Д. Василик, С.В. Васильчак, В.П. Вишневський, О.Р. Жидяк, Т.І.Єфименко, С.В. Каламбет, А.І. Крисоватий, М.П. Кучерявенко, І.О. Луніна, П.В. Мельник, О.О. Непочатенко, В.П. Синчак, А.М. Соколовська, Л.Д. Тулуш, В.М. Федосов, С.І. Юрій та інші автори. Завдяки їхнім працям, в Україні вдалось змінити ставлення як до оподаткування загалом, так і до непрямих податків зокрема, однак значна частина питань залишається і сьогодні малодослідженою.

Мета статті є визначення напрямів удосконалення акцизного оподаткування до норм Європейського Союзу.

В Україні адміністрування і ПДВ, і акцизного податку потребує удосконалення та наближення до норм податкової системи ЄС для подолання проблеми тіньового обігу продукції та ухилення від сплати визначених законодавством податкових платежів.

Акцизний податок як один з основних непрямих податкових платежів до бюджету, який справляється як з підакцизних товарів, які виробляються на території України, так і товарів, що ввозяться на її територію, займає одне з ключових місць в питанні наповнення державного бюджету. Відтак, проведення оптимізації справляння даного податку та гармонізації з правилами акцизного оподаткування країн-членів ЄС слід реалізувати з урахуванням можливих ризиків для економіки держави. Загалом, згідно угоди про асоціацію, а саме розділу $\mathrm{V}$ «Економічне та галузеве співробітництво» четвертої глави, вітчизняне законодавство слід привести відповідно до положень таких Директив ЄС:

1. Директиви Ради 2008/118/€С від 16.12.2008 року про загальний режим акцизних зборів (вимога фрормування 
ідентичних умов та концептуальних засад оподаткування акцизним податком в усіх державах-членах $Є C$ );

2. Директиви Ради 92/83/ЄЕС від 19.10.1992 року про гармонізацію структур акцизних зборів на алкоголь та алкогольні напої;

3. Директиви Ради 2011/64/€С від 21.06.2011 року про структуру та ставки акцизного збору на тютюнові вироби (кодифікація);

4. Директиви Ради 2003/96/ЄС від 27.10.2003 року про реструктуризацію системи Співтовариства щодо оподаткування енергоносіїв та електроенергії.

Так, серед основних проблем, які слід подолати в напрямку гармонізації, передовсім слід звернути увагу на такі:

- неузгодженість ставок щодо підакцизних товарів в реаліях вітчизняної податкової системи та фіскальної системи ЄC;

- неточності та неспівпадіння визначення об'єктів оподаткування в даних системах;

- існування схем ухилення від сплати акцизного податку та контрабанди товарів;

- неефективна, складна та непрозора система адміністрування акцизного податку в Україні;

- існування та розвиток «тіньового» сектору економіки, що прямо впливає на суми надходження податку до бюджетів;

- відмінності пільгового оподаткування акцизним податком та його поширеності на монопольні і товари з високим рівнем рентабельності в Україні та країнах-членах ЄС.

Перше, на що варто звернути увагу у зв'язку з підписанням економічної та секторальної частин угоди «Про асоціацію між Україною та ЄС» є поступове наближення ставок акцизного податку до розмірів відповідних ставок в Європі. Таке підвищення на 33\% Україною було застосовано для фрормування передумов для вступу до ЄС. Дана ситуація є наслідком необдумано швидкої «гармонізації» законодавства в ссрері акцизного оподаткування, який відчули громадяни таких країн як Болгарія, Латвія та Румунія. Через необдумане підвищення ставок акцизу на тютюнові вироби відбулося стрімке зростання показника вживання саме контрабандної та нелегальної продукції - у 2010 році ці показники зросли до $27 \%$ у Румунії, 41\% - в Латвії, 32\% - в Болгарії. Окрім того, відбулося зменшення надходження до бюджетів даних країн акцизного податку.

Схожа ситуація спостерігалася і в Україні в період 2008-2011 pp. Різке підвищення ставок акцизного податку відбулося відповідно до умов антикризової політики та вимог конвенції Всесвітньої організації охорони здоров'я (ВОО3). Внаслідок росту надходжень акцизного податку до державного бюджету, через збільшення вартості продукції, частина населення з низьким рівнем платоспроможності була змушена шукати більш дешевий товар, що призвело до зростання попиту на контрабандну продукцію з країн, де ставки акцизу на відповідну продукцію $є$ значно нижчими. Відтак, наслідком даної ситуації в економічному розвитку держави стало падіння виробництва тютюнових виробів на 24,4\% за п'ятиріччя після підвищення акцизу та зростання торгівлі нелегальною продукцією на 9,2\% [1].

В даному контексті розгляду проблем при підвищенні акцизу на тютюнові вироби, слід звернути увагу на ще одну притаманну для вітчизняної податкової системи проблему, характерну для споживчого ринку в період підняття акцизного податку на тютюнові вироби. Так, внаслідок існування доволі великої різниці в обкладанні акцизним податком сигарет з фільтром та без фільтру, при піднятті ставок акцизного податку, попит зросте на більш дешевші сигарети без фільтру, що може негативно позначитися на доходах державного бюджету [1].

В країнах ЄС такої проблеми немає через те, що, відповідно до норм Європейського Союзу, класифікації сигарет на сигарети з фільтром та без фільтру немає, і тому ставки оподаткування акцизом в даному випадку є єдиними. При цьому, це не лише практика країн ЄС, а й, наприклад, Казахстану та Росії. Відтак, пропозиція приведення до єдиної ставок на дані види сигарет сьогодні в рамках підняття усіх ставок акцизного податку є особливо актуальною та навіть необхідною.

Слід зауважити, що впродовж 2008-2015 років ставка акцизного податку на пачку сигарет зросла в 14 разів, що наслідком мало ріст надходження до бюджету з 3,5 млрд. грн. у 2008 році до 22,2 млрд. грн. у 2015 році та скорочення обсягу продажів тютюнових виробів зі 125 млрд. грн. до 73 млрд. грн., що звичайно ж позначилося і на зростанні проблеми нелегальної тютюнової продукції [2]. На 2017 рік також відбувся ріст ставки оподаткування акцизним податком на тютюнові вироби на 30\% [3], таке ж збільшення відбулось і у 2018 році.

Відтак, при неминучості підвищення ставок акцизного податку на тютюнові вироби відповідно до вимог та норм Європейського Союзу, слід мінімізувати можливості росту контрабанди даної продукції на територію України з країн, де акцизи та ціни на неї значно нижчі, та нелегальне виробництво тютюнової продукції шляхом поетапного та поміркованого підвищення ставок акцизу впродовж відповідного періоду та врахування регіонального контексту і економічної ситуації в країні (девальвації гривні та появи «сірої зони» на Донбасі) (рис. 1).

Окрім того, особливо важливим є врахування, як уже згадувалося, регіонального контексту зміни ставок акцизного оподаткування. Так, в Україні слід підвищити середній розмір ставок акцизного податку до середнього по регіону. Проте, враховуючи те, що на даний час Україна виступає в ролі нетто-експортера нелегально виробленого тютюну за кордон, при підвищенні ставок акцизу та їх наближенні до середніх в Росії, яка виступає найбільшим ринком регіону, що автоматично означатиме нижчі ставки в Білорусії та Молдові, вона може перетворитися на нетто-імпортера нелегального тютюну та трансфрертну зону контрабанди через «сіру зону» на Донбасі, що, окрім передбачених наслідків для вітчизняного виробництва, матиме наслідком росту фінансової незалежності бандитських формувань на Сході України.

Дані пропозиції стосуються не лише аналізованого вище ринку тютюнових виробів в Україні, а й інших підакцизних товарів, зокрема, ринку алкогольних напоїв.

Зважаючи увагу на основну проблему гармонізації оподаткування акцизом товарів в Україні до відповідних норм та правил Європейського Союзу, існують і інші, на яких слід наголосити. Так, важливою проблемою, яка суперечить самій природі акцизного податку як податку на споживання, $є$ запровадження механізму авансової сплати акцизного податку при купівлі акцизних марок без орієнтування на питання реалізації продукції. 
Введення даного механізму мало на меті забезпечити спрощення процедури декларування акцизу та усунення проблеми махінацій з роздрібними цінами на тютюн та тютюнові вироби. Але на даний час даний механізм є протиставленням не лише суті існування акцизного податку, але й вимогам Європейського Союзу в сфері адаптації податкового законодавства.

Так, згідно статті 7 Директиви Ради 2008/118/ЄС від 16.12.2008 року про загальний режим акцизних зборів, даний податок характеризується тим, що податкові зобов'язання ви- никають в момент випуску підакцизних товарів для їх споживання. А відповідно до пункту 216.1 статті 216 Податкового кодексу України, датою виникнення податкових зобов'язань для товарів, що виготовлені на території України, є дата їх реалізації. Відтак, об'єктом оподаткування даним видом фріскального платежу є реалізація продукції (стаття 213 Податкового кодексу), що свідчить наявність розбіжностей між нормами Податкового кодексу України та Директивою Ради 2008/118/€С у визначенні поняття об'єкта оподаткування та дати виникнення податкових зобов'язань $з$ акцизного податку.

Зниження ризиків зростання контрафракту, контрабанди та нелегального експорту підакцизних товарів

Гармонізація акцизних ставок у відповідності до вимог Угоди про асоціацію з ЄС

\begin{tabular}{|c|c|}
\hline \multicolumn{2}{|c|}{ РЕГІОНАЛЬНИЙ КОНТЕКСТ } \\
\hline Врахування регіонального & Формування графіку \\
\hline аспекту рівня акцизних ставок & підняття акцизів 3 \\
& урахуванням акцизної \\
& політики країн регіону \\
\hline
\end{tabular}

Підняття ставок акцизного податку відповідно до змін рівня добробуту населення

Рис. 1. Гармонізація акцизних ставок відповідно до норм ЄС
Примітка. Розроблено автором.

Зважаючи на те, що вживання підакцизних товарів в основному $є$ шкідливим для здоров'я, то однією з фрункцій держави, зокрема через використання механізму акцизного оподаткування, є забезпечення зниження рівня їх споживання. В цьому випадку, варто відмітити пропозицію включення до об'єкта оподаткування акцизним податком операцій з надання маркетингових послуг виробникам підакцизної продукції (рис. 2).

Вплив на зростання вживання населенням шкідливих для організму товарів, таких як горілка, пиво, інші алкогольні напої, а також тютюнові вироби, здійснюється першочергово через рекламу такої продукції на вітчизняному телебаченні, в $3 \mathrm{MI}$ та на зовнішніх носіях реклами. В Україні цей процес не регулюється на належному рівні, хоча і визначено окремі аспекти транслювання реклами таких виробів на телебаченні.

Натомість, у країнах-членах ЄС реклама алкогольних та тютюнових виробів заборонена відповідно до Директиви 89/552/ЄЕС про транскордонне телебачення. Слід зауважити, що обмеження реклами не стосується лише зазначених підакцизних товарів, що є шкідливими для здоров'я. В країнах $€ С$ реклама на соціальних каналах обмежується, а її транслювання здійснюється в основному на комерційних каналах. Так, для прикладу, у Хорватії реклама на телебаченні має займати не більше $9 \%$ ефірного часу, у Франції - рекламу заборонено транслювати після 20:00, а у Чехії - прибутки з реклами на публічних каналах надходять до місцевих бюджетів.

Маркетингова діяльність включає в себе комплекс заходів, спрямованих на просування певного товару на ринку та забезпечення максимізації прибутків з його реалізації, через проведення дослідження відповідного сегмента ринку та прогнозування його зміни, розробку тактичних та стратегічних кроків просування товару та формування та використання стим улів збільшення попиту на нього з боку потенційних споживачів.

До сукупності таких заходів відносяться: проведення дослідно-аналітичної роботи; процес позиціонування товару та обрання цільового сегмента ринку; розробка цінової політики підприємства по відповідному товару; формування політики руху продукції; просування товару на ринку через використання інструментів стимулювання попиту на товар, його рекламу, PR та систему особистих продажів.

Платником податку слід вважати особу, яка здійснює маркетингову діяльність 3 метою збільшення об'ємів продажу, забезпечення такого ж рівня продажу або запобігання падінню рівня продажу тютюну, спирту етилового алкогольних напоїв та пива.

Об'єктом оподаткування є операції з надання маркетингових послуг виробникам підакцизної продукції

Базою оподаткування варто вважати договірну (контрактну) вартість маркетингової послуги, а саме: вартість понесених витрат, що спрямовані на вивчення ринку та витрат на просування товару на ринку з метою збільшення надходжень від його реалізації.

Датою виникнення податкових зобов'язань у виробника послуги при постачанні маркетингової послуги $€$ дата оформлення документа, що засвідчує факт постачання маркетингової послуги.

Факт постачання маркетингової послуги від виробника (маркетингової фрірми) до споживача (виробник підакцизної продукції) послуги підтверджують такі документи: договір про проведення маркетингових досліджень, акт прийманняпередачі послуг або документ, що підтверджує цю дію, звіт про проведення маркетингових досліджень, платіжне доручення.

Важливо зауважити, що в даному випадку доцільно 
використовувати адвалорну ставку акцизного податку, яка є ефективнішою, оскільки при використання твердих ставок в умовах інфляції можливе скорочення надходжень до бюджету, а відсоткових - можливе зростання надходжень при одночасному підвищенні цін.

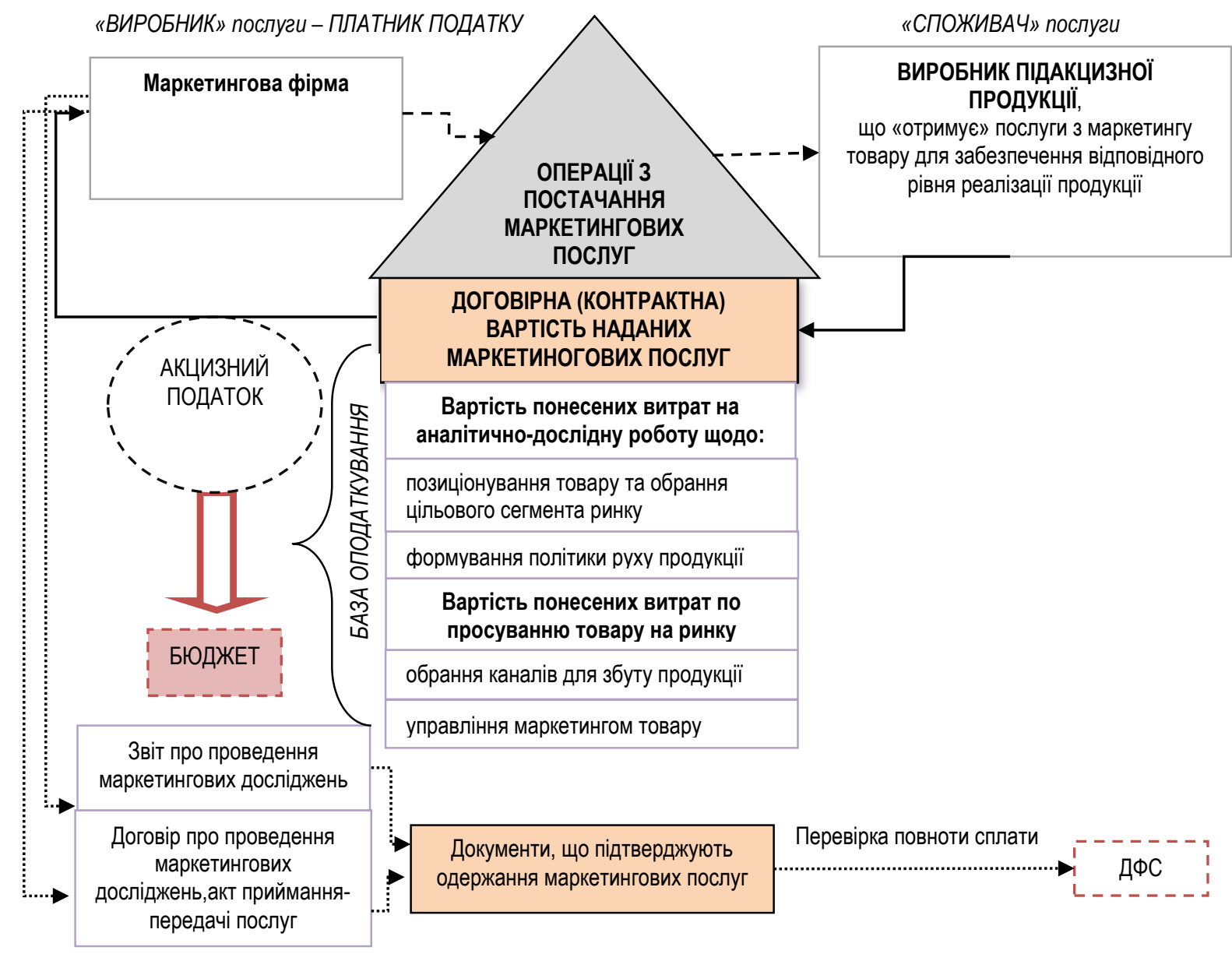

Рис. 2. Схема оподаткування акцизним податком маркетингових послуг, наданих підприємствам-виробникам алкогольної продукції/тютюнових виробів

Джерело: розроблено автором

Відтак, наслідками запровадження акцизного податку на маркетингові послуги, що надаються підприємствам-виробникам алкогольної продукції/тютюнових виробів, буде:

1. додатковий інструмент контролю за вживанням шкідливих товарів з боку держави;

2. зростання надходжень до бюджету від оподаткування акцизом;

3. відсутність прямого впливу на безпосередніх споживачів продуктів;

4. можливість формування простої системи адміністрування даного податку та контролю за його сплатою.

Важливим питанням, яке потребує першочергової уваги є встановлення пільг при оподаткуванні акцизним податком. Так, різницею встановлення пільг в Україні та ЄС є існування так званих галузевих пільг (автомобілебудування, виноробство), а також існування в якості основної пільги звільнення від оподаткування акцизом певних товарів та операцій. Натомість, в ЄС застосовується система знижених ставок, які не можуть складати менше $1 / 2$ стандартної ставки. При цьому, встановлення пільг в країнах ЄС має конкретне спрямування - підтримку виробництва національного продукту, який або характеризується географічною назвою, або його виробниц- тво здійснюється згідно відповідної рецептури (історично передбаченої) (Директива Ради 92/83/ЄЕС). Тому, в Україні доцільним було б переглянути систему надання пільг зі сплати акцизного податку в напрямку наближення до норм ЄС та їх формування відповідно до таких векторів:

- підтримка виробництва національного продукту, який характеризується історією свого виготовлення та відповідною рецептурою;

- підтримка малих виробників в сфері виготовлення алкогольних напоїв, зокрема, виноробів.

При розгляді питання удосконалення системи справляння акцизного податку особливо важливим $€$ спрощення адміністрування даного податку. Як і в питанні ефективної системи адміністрування податку на додану вартість, яка детально розглядається в наступному питанні та частково в попередньому, для досягнення цієї мети необхідним $є$ формування електронної системи адміністрування акцизного податку та використання цифрових технологій маркування. Прикладом ефективного використання та функціонування такої системи $є$ Codentify, яка впроваджена та активно використовується в Швейцарії, вивчена та схвалена як якісна Інтерполом та Європейським бюро по боротьбі з шахрайством [1]. Дана система забезпечує: 
- можливість відстеження руху відповідної продукції в режимі реального часу;

- можливість контролю за виробництвом та реалізацією продукції;

- моніторинг сплати акцизного податку до бюджету;

- можливість визначення якості продукції (через визначення її автентичності) з боку і державних органів, і самих споживачів.

Враховуючи той факт, що вітчизняні товаровиробники - платники акцизного податку технологічно можуть бути користувачами такої електронної системи адміністрування та контролю можуть отримати від цього свої переваги, а її запровадження - питання часу та готовності держави.

Таким чином, основними напрямами удосконалення оподаткування акцизним податком мають стати такі $[5,6]$ :

1. адаптація вітчизняної системи законодавчого обґрунтування справляння акцизного податку до норм та вимог ЄС в питаннях гармонізації бази та об'єктів оподаткування, термінології та податкових ставок;

2. спрощення системи адміністрування шляхом запровадження електронної системи адміністрування акцизного податку та використання цифрових технологій маркування;

3. розширення переліку підакцизних товарів через оподаткування товарів розкоші, зокрема, ювелірних виробів, та бази оподаткування (оподаткування акцизним податком витрат маркетингової діяльності підприємств-виробників алкогольної продукції/тютюнових виробів);

4. врахування факторів розвитку акцизного оподаткування в регіоні, ситуації зміни рівня добробуту населення та рівня адаптації економіки та населення до відповідних нововведень та змін при гармонізації акцизних ставок відповідно до норм ЄС для ухилення від можливих ризиків росту контрабанди, конрафакту та нелегального експорту;

5. формування системи пільгового оподаткування при стягненні акцизного податку відповідно до вимог ЄС та з метою підтримки виробника національного продукту та малих виробників.

Висновки. Розглядаючи питання удосконалення справляння акцизного податку до державного бюджету, слід визначити основні напрямки даного процесу:

- передовсім, це питання автоматизації процесів адміністрування справляння податків та митних платежів, що забезпечить обмеження впливу людського фактора на систему оподаткування;

- гармонізація законодавчої системи в сфері акцизного та митного оподаткування до норм та правил Європейського Союзу;

- формування акцизної та митної політики з пріоритетністю підтримки національного виробника та малого бізнесу;

- можливості збільшення надходжень до бюджету від оподаткування акцизним податком при збереженні рівноваги податкового навантаження.

\section{Список використаної літератури:}

1.Наповнення бюджету шляхом удосконалення акцизної політики в Україні // Моніторинг біржового ринку. 2014 . № 7. С. 28-31. Режим доступу: http://nbuv.gov.ua/UJRN/mbr_2014_7_6.

2.Бочі А., Поворозник В., Жолудь О. Вплив зміни ставок на тютюнові вироби на деякі економічні та соціальні показники в контексті Угоди про асоціацію з ЄС. Міжнародний центр перспективних досліджень. 2014. 42 с.

3.Мінфін хоче підвищити акцизи на алкоголь і тютюн. Економічна правда. - 14 вересня 2016 р. Режим доступу: http://www.epravda. com.ua/ news/2016/09/14/605472.

4.Податковий кодекс України. Верховна Рада України; Кодекс України, Закон, Кодекс від 02.12.2010 № 2755-VI. - Режим доступу: http://zakon5.rada.gov.ua/laws/show/2755-17/page.

5.Пелехатий А.О. Бюджетна політика у забезпеченні розвитку територій: концептуальні домінанти та напрями модернізації: [монографія] / А.О. Пелехатий. Львів: Львівський національний університет імені Івана Франка, 2019. 386 с.

6.Пелехатий А.О. Обгрунтування нової парадигми бюджетної політики розвитку територій в умовах реформування публічних фінансів в Україні. Електронне наукове фахове видання «Ефективна економіка», №7, 2019 [Електронний ресурс]. Режим доступу: http://www.economy.nayka.com.ua/?op=1\&z=7191

\section{References:}

1.Monitoring the stock market (2014). Napovnennia biudzhetu shliakhom udoskonalennia aktsyznoi polityky v Ukraini [Filling the budget by improving the excise policy in Ukraine]. Vol. 7. pp. 28-31. Retrieved from: http://nbuv.gov.ua/UJRN/mbr_2014_766. [in Ukrainian].

2.Bochi A., Povoroznyk V., Zholud O. (2014). Vplyv zminy stavok na tiutiunovi vyroby na deiaki ekonomichni ta sotsialni pokaznyky v konteksti Uhody pro asotsiatsiiu z YeS [Finansovo-ekonomichnyi potentsial terytorialnykh hromad: mekhanizmy formuvannia ta aktyvizatsii]. Mizhnarodnyi tsentr perspektyvnykh doslidzhen. 42 p. [in Ukrainian].

3.Minfin khoche pidvyshchyty aktsyzy na alkohol i tiutiun. Ekonomichna pravda. - 14 veresnia 2016 r. Retrieved from: http://www.epravda. com.ua/ news/2016/09/14/605472. [in Ukrainian].

4.Supreme Council of Ukraine (2010). Podatkovyj kodeks Ukrai'ny [Tax Code of Ukraine] (Adopted on 2010, December 2, 2755-VI). Retrieved from http://zakon5.rada.gov.ua/laws/show/2755-17/page. [in Ukrainian].

5.Pelekhatyi A.O. (2019). Biudzhetna polityka u zabezpechenni rozvytku terytorii: kontseptualni dominanty ta napriamy modernizatsii [Budget Policy in Territorial Development: Conceptual Dominants and Directions for Modernization]. Lviv: Lvivskyi natsionalnyi universytet imeni Ivana Franka, 386 p. [in Ukrainian].

6.Pelekhatyi A.O. Obhruntuvannia novoi paradyhmy biudzhetnoi polityky rozvytku terytorii v umovakh reformuvannia publichnykh finansiv v Ukraini [Substantiation of the new paradigm of budgetary policy of territorial development in the context of public finance reform in Ukraine]. Efektyvna ekonomika - Effective Economics, №7. Retrieved from: http://www.economy.nayka.com.ua/?op=1\&z=7191. [in Ukrainian]. 
Yarosh M., PhD, The apparatus of the Verkhovna Rada of Ukraine (Kyiv, Ukraine)

Prokipchuk L., PhD student, Ivan Franko National University of Lviv (Lviv, Ukraine)

Galamaj R., PhD student, Ivan Franko National University of Lviv (Lviv, Ukraine)

Improvement of excise taxation in Ukraine under EU integration

The article explores the issues of improving excise taxation in Ukraine in the context of integration of national legislation with the requirements of the European Union. The above mentioned EU Directives under which domestic legislation should be brought into line. The main problems that need to be addressed in the direction of harmonization of national regulatory acts with EU requirements are identified. The scheme of excise taxation of marketing services provided to enterprises producing alcoholic products / tobacco products is proposed. The consequences arising from the introduction of an excise tax on marketing services provided to enterprises producing alcoholic beverages / tobacco products are indicated. It is recommended to review the system of providing excise tax benefits in the direction of approximation to EU norms and to form them in accordance with the following vectors: support for the production of a national product characterized by its history of manufacture and the corresponding formulation; support for small producers of alcoholic beverages, including winemakers. The main directions of improvement of excise tax are defined, namely: adaptation of the domestic system of legislative justification of excise tax to EU norms and requirements; simplification of the administration system through the introduction of an electronic excise tax administration system; expanding the list of excise goods through taxation of luxury goods; taking into account the factors of excise tax development in the region; formation of a system of preferential taxation in case of collection of excise tax in accordance with EU requirements. As a conclusion, it is necessary to first of all take the following measures to effectively harmonize tax and customs legislation with the EU norms: automation of the processes of administration of tax and customs payments; harmonization of the legislative system in the field of excise and customs taxation; formation of excise and customs policy with priority of support of national producer and small business.

Key words: excise tax, European Union, association, customs payments, taxation of marketing services.

Дата надходження до редакції: 27.10.2019 p. 